varied from six weeks upward. In eleven cases therc was marked diminution even to complete disappearance. In five othcrs there was considerahle hut not so marked improvement. In the remaining cases the treatment was without result. In tlie fivc coses in which the treatment was only partially successful, potnssium iodidc internally and iodine ointment externally also failed. Four patients, who wcre seen from three to five months after the cessation of treatment, were found to he in the same condition os at its close. The explanation heing apparently that in hyperplastic struma the gland substance functionally hypcrtrophies, and upon the administration of the extract this hypertrophy retrogrades, provided that sccondary changes have not superrened.-Wiener Llinische Wochenschrift, 1895, No. 41, S. 715.

\title{
ThE TREATMENT OF ZOSA.
}

M. Albert RoBri commences with the administration of a salinc purgative, preferahly sodium sulphate. For the cruption it is essential that it he kept dry. The application recommended, which will also relicve the pain, is composed of powdered starch, 60; zinc oxide, 15 to 20 ; pordered camphor, 1 to 3 ; and finely powdered opium, 1 part. In old people the cruption should be closely witched to prevent ulceration. The neuralgia which precedes and accompanies the eruption is trented by four pills daily, ench containing onesixth of a grain of cxtract of datura stramonium nad extract of gelsemium, and onc-twelfth of a grain of cxtract of belladonna. If these pills should fail antipyrin is to he substituted. For the neuralgia consecutive to the eruption subcutiaeous injections of antipyrin are employed; or those of sodium glscero-phosphate.-Bulletir général de Thérapeutigue, 1895, 40 liv., p. 358.

\section{Tre Treatuest of Ltuabago.}

MI. ALBEnt RoBrs mentions the various local applications with friction which hare hecn used from timc immemorial, revulsives, counter-irritants, and wet-cups. Of the applications, massage of the joints, clectricity, particularly for the secondary muscalar atrophy, and methyl-chloride for the acute stage, are especially mentioned. For the internal treatment jaborandi is most strongly recommended. As contra-indicntions to its use should he cited disturhances in the cardinc rhythm, and it should bc omitted if epistaxis or the quantity of urine does not reach the normal amount after diaphoresis. The method of preparation is as follows: Sixty grains of the leares are macerated for twelre to twenty-four hours in two and one-half drachms of alcohol. Upon this mixture is ponred one and one-half onnces of boiling water, which is infused for twenty-four minutes and then filtered. The filtrats is taken hot, as it is prepared, in the morning, fasting. During the perspiration the patient should nvoid swallowing the saliva, which may give rise to nausen or even to vomiting, nnd for the thirst he should drink only a small quantity of warm liquids, diluted coffee, in order to avoid the vomiting which follows the immoderate ingestion of cold liquids or the swallowing of a certain quantity of saliva. There are instances when a single dose of the remedy will cure the disense. In case it is necessary to repeat the treatment, it is well to have a day of intermission between the doses. 
The patient should be kept warm, confined to his room or even in hed. In case that this remedy is contraindiented, sodium glycero-phosphate, five to scren grains, hypodermatically ean be substituted. In certain cases when the articulations are affected sodium salicylate may he of use, hut it is not so valuahle as is jahorandi.-Bulletin général de Thérapeutique, 1895, 36 liv., p. 241.

\section{MEDIOTNE.}

UXDER THE CHAHGE OF

TILLIAIY OSLER, M.D.,

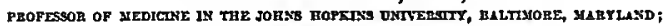

AXD

GEORGE DOCK, MI.D.,

PROFESSOR OP MEDICERE IN THE UXIVERATTY OF MUCHOAN.

\section{ALCOHOLIC MYYOCARDITIS.}

AOrgecat (Deuisches Archiv für Llin. Med., Bd. liv. p. 615) calls attention to a class of cases not hitberto recognized. The disease usually occurs in men between tbe ages of twenty.fire and fifty, but in o ne case appeared in a man nineteen years old. Brewers and inn-kcepers form n large proportion of cases; women are rarely affected. All the paticnts admit excessive use of alcoholics. That all who indulge in the same way are not affected may be due to mode of life, to exercise, temporary periods of abstinence, or other unknown eauses. The diseage begins gradually. Most patients in tbe beginning are well nourisbed. The first symptom is dyspnas, whicb may be noticed in talking; in morc adranced stages on climbing stairs. A feeling of pressure in the beart region is not uncommon. Tbe patients are usunlly able to continne their business, especially wben it does not involve severe bodily lahor. On account of the course of the disease tbe heart-the organ first affected-is rarcly examined in the earliest stages. Cases examined at such times show an enlargement of the cardiac dulness, rarely a murmur. Aufrecht considers the lesion in the beart to he at first dilatation from the effect of the alcohol on the muscle; this is followed hy hypertrophy of the muscular fibres and their nuclei, incrense of connective tissue, thickening of the smaller arteries with increase of nuclei in their walls, and, finally, fragmentation of the muscle-fibre. For these lesions Aufrecht prefers the term nt the head of this article. At an esrly period of the disense the liver is enlarged, pcrhaps on account of the dilatation of the heart. though the autlor thinks more probahly from inflammatory changes due to alcohol. Later, cirrhosis occurs, either atrophic or hypertrophic; in some cases there is peri-hepatitis. Congestion of the kidneys nlso occus, with temporary alhuminuria. In onc case uramic mania with alhuminuria gave the first indication of the kidney affection, the attack being hrought on hy a wine-dinner. In another cusc there was teinporary diabetes. Alcoholic myocarditis was at 